\title{
Effect of Intercropping Maize with Cowpea on the Yield and its Quality
}

\author{
Elsaid, Samah M.; M.A. Elmorshedy; Anaam H. Galal; F.M.F. Abdel- \\ Motagally and M.A.M. Abdullah \\ ${ }^{1}$ Agronomy Dept., Fac. Agric. Assiut Univ., Assiut, Egypt \\ ${ }^{2}$ Animal production Dept., Fac. Agric. Assiut Univ., Assiut, Egypt \\ Received on: 6/8/2019 \\ Accepted for publication on: 1/9/2019
}

\begin{abstract}
A field experiment was conducted at the Agronomy Department Farm, Faculty of Agriculture, Assiut University Egypt., during two summer growing seasons of 2017 and 2018 to study the relative advantage of intercropping systems of maize with cowpea on the yield and its attributes as well as some quality traits. The experiment was laid out in randomized complete block design with four replicates. Treatments were sole maize, sole cowpea and five planting patterns of maize intercropped with cowpea.

The obtained results revealed significant variations among the intercropping treatments for the all studied maize traits, except ear length and 100 grain weight. In addition, sole planting for maize hybrid 128 surpassed sole planting for maize hybrid 131 and the other intercropping patterns with regard to grain yield feddan ${ }^{-}$ ${ }^{1}$ and gained the maximum grain yield feddan ${ }^{-1}$ which was 38.82 ardab feddan ${ }^{-1}$. Furthermore, the obtained data show highly significant variations among the intercropping treatments for the all studied cowpea traits. Thus, Sole cowpea crop produced highly significant forage yield (11.59 ton feddan-1 as summation of two cuts) than intercrop patterns. Here too, sole cowpea crop registered the minimum fiber percent as compared with intercrop patterns. Otherwise, the highest mean value of protein percentage $(17.30 \%)$ was recorded from intercrop maize with cowpea 1:2 or 2:1 rows.

The land equivalent ratio The for most intercropping systems was greater than one, indicating that intercropping was more efficient than sole cropping in utilizing the available resources and resulted in higher productivity.
\end{abstract}

Keywords: Maize, Cowpea, Intercropping, land equivalent ratio.

\section{Introduction}

Intercropping is a type of mixed cropping which was defined as cultivating two or more crops in the same soil at the same time. The major reason to grow two or more crops together may be increase of productivity of land. Hence, intercropping can provide many benefits through increased efficiency of land use, enhancing the capture and use of light, water and nutrients, controlling weeds, insects, diseases and increasing the length of production cycles
(Hamd Allah et al., 2014). Other benefits of intercropping may be improving seed quality, and controlling water quality through minimizing the use of inorganic $\mathrm{N}$ fertilizers, replacing them by the use of legumes.

There is a big deficit in summer forage crops in Egypt. Defoliation of maize is commonly used to feed animals. This resulted in decreasing maize yield. Thus, intercropping of forage crops such as cow pea with cereal crops, such as maize reduce the 
green fodder gab during summer season.

Previous studies indicated that intercropping cowpea with maize significantly increased plant height in both crops and grain yield of maize in the first season and reduced it in the second season, but cowpea yield was reduced in the both seasons (Okpara, $2000)$. Grain yield of cowpea was reduced by $43 \%$ and $33 \%$ in intercropping and relay cropping, respectively (Polthanee and Butchareon, 2000). Maize intercropped with cowpea produced the highest grain yield and the lowest values of associated weeds (Zohry, 2005). Grain yield of maize was observed the highest when maize intercropping with cowpea cultures. In monoculture the yield of cowpea was higher, while the lowest yield was obtained when cowpea sown with maize. The highest land equivalent ratio was obtained from corn with cowpea (Shata et al., 2007). Hamd Alla et al. (2014) revealed that intercropped maize plants with cowpea, exhibited greater potentiality and resulted in higher values of plant height, number of ears/plant, number of rows/ear, number of grains/row, grains weight/ear, 100-grain weight and straw and grain yields. Fresh and dry forage yields of cowpea were lower in intercropping with maize than sole. Furthermore, the combined of the two seasons revealed that the total Land Equivalent Ratio (LER) between cowpea and maize was 1.65.

Therefore, the main target of this research was to study the effect of intercropping maize with Cowpea intercropping on yield and its components.

\section{Materials and Methods}

A field experiment was conducted at the Agronomy Experimental Farm, Faculty of Agriculture, Assiut University Egypt, during 2017 and 2018 seasons to study the relative advantage of intercropping systems of maize with cowpea on the yield and its attributes as well as cowpea forage quality. Some physical and chemical properties of a representative soil sample used in the experimental soil were determined before preparation Table (1).

Table 1. Some physical and chemical properties of a representative soil samples in the experimental site before sowing $(0-30 \mathrm{~cm}$ depth) in 2011/2012 and 2012/2013 seasons.

\begin{tabular}{|l|c|c|}
\hline \multicolumn{1}{|c|}{ Character } & $\mathbf{2 0 1 7}$ & $\mathbf{2 0 1 8}$ \\
\hline Particle size distribution & 27.7 & 26.8 \\
\hline Silt (\%) & 25.7 & 24.4 \\
\hline Sand (\%) & 48.4 & 48.8 \\
\hline Clay (\%) & Clay silty & Clay silty \\
\hline Texture & 1.84 & 1.82 \\
\hline Organic matter (\%) & 42.60 & 43.6 \\
\hline Field capacity (\%) & 0.88 & 0.85 \\
\hline ECe (ds/m) & 7.60 & 7.82 \\
\hline pH (1:1 suspension) & 0.78 & 0.74 \\
\hline Total nitrogen (\%) & 3.46 & 3.68 \\
\hline CaCO $\%$ & 8.50 & 8.72 \\
\hline Extractable P (ppm) & 122 & 123 \\
\hline Extractable K (ppm) & & \\
\hline
\end{tabular}

* Each value represents the mean of three replications. 
The trial was established in randomized complete block design (RCBD) with four replications.

Thirteen treatment were used which were

$$
\text { T1 - Hybrid } 128 \text { (H128) Sole }
$$

T2- H128 /Cowpea in the same row different side

T3- Row H128: row cowpea

T4- Row H128: two rows cowpea

T5- Two rows H128: row cowpea

T6- Two rows H128: two rows cowpea

T7- Hybrid 131 (H131) Sole

T8- H131/Cowpea in the same row different side

T9- Row H131: row cowpea

T10- Row H131: two rows cowpea

T11- Two rows H131: row cowpea

T12- Two rows H131: two rows cowpea

T13- Sole cowpea

The experimental unit area was $10.5 \mathrm{~m}^{2}$. Sowing was take place on 5 and 6 June for two crops in 2017 and 2018 seasons, respectively. Cowpea and maize seeds were sown at $25 \mathrm{~cm}$ within a row and $70 \mathrm{~cm}$ between rows. The preceding winter crop was wheat in both seasons. All other cultural practices recommended for maize and cowpea crops were done in both seasons.

\section{Studied Traits}

\section{A. For Maize}

The plants of each plot were harvested at the end of the growing season (110 days from planting) and the ears were separated, air dried for 2 weeks, then total weight of ears plot $^{-1}$ and ten plants were chosen at random from each plot at harvest to determine: plant height $(\mathrm{cm})$, Ear length $(\mathrm{cm})$, Number of rows ear ${ }^{-1}$, 100-grain weight $(\mathrm{g})$, Grains weight (g) ear ${ }^{-1}$ then total weight of ears/plot were used to determine the Grain yield ( $\left.\mathrm{kg} \mathrm{fed}^{-1}\right)$.

\section{B. For Cowpea}

Two cuts of cowpea were harvested (either sole or intercropping) first cut was done at 70 days after sowing and the second at 40 days after the first cut. Traits studied over all cuts fresh forage yield (ton/fed.), dry forage yield (ton/fed.), fiber and protein contents. Crude protein was determined using Kjeldhal method while the crude fibre was determined according to A.O.A.C. (1995).

\section{Land Equivalent Ratio (LER)}

Land Equivalent Ratio (LER) which verifies the effectiveness of intercropping for using the resources of the environment compared to sole cropping as indicated by Willey and Osiru (1972).

The LER values were calculated as: LER $=($ LERM + LERC $)$, where $\mathrm{LERM}=\mathrm{YIM} / \mathrm{YM}$ and $\mathrm{LERC}=$ $\mathrm{YIC} / \mathrm{YC}$, where $\mathrm{YM}$ and $\mathrm{YC}$ are the yields of maize and cowpea as sole while YIM and YIC are the yields of maize and cowpea as intercrops, respectively.

\section{Statistical analysis:}

All collected data were analysed with analysis of variance (ANOVA) Procedures, using the SAS Statistical Software Package v.9.2 (SAS, 2008). Bartlett test was used to assess the variance of experimental error of both seasons according to Snedecor and Cochran (1989), then combined analysis for two years was done. Differences between means were compared by the least significant difference (LSD) at 5\% level of significant (Gomez and Gomez, 1984). 
Results and Discussion

A. Effect of Cowpea with Maize Intercropping on Maize Characters

The combined analysis of variance, presented in Table 2, revealed significant variations among the intercropping treatments for all studied maize traits except ear length and 100 grain weight.

Table 2. Combined analysis of variance for studied maize traits over two years.

\begin{tabular}{|l|c|c|c|c|c|c|c|}
\hline \multicolumn{1}{|c|}{ S.O.V } & d.f & $\begin{array}{c}\text { Plant } \\
\text { Height } \\
(\mathbf{c m})\end{array}$ & $\begin{array}{c}\text { Ear } \\
\text { Length } \\
\mathbf{( c m )}\end{array}$ & $\begin{array}{c}\text { Number } \\
\text { of rows } \\
\text { /Ear }\end{array}$ & $\begin{array}{c}\text { Weight of } \\
\mathbf{1 0 0} \\
\text { grains (g) }\end{array}$ & $\begin{array}{c}\text { Grain } \\
\text { weight /Ear } \\
(\mathbf{g})\end{array}$ & $\begin{array}{c}\text { Grain } \\
\text { Yield } \\
\text { (Ardab) }\end{array}$ \\
\hline Year (Y) & 1 & 1436.48 & 3.41 & $2.14 * *$ & 31.72 & 5134.22 & 3.41 \\
\hline Error Y & 4 & 235.86 & 60.53 & 0.11 & 6.56 & 770.78 & 60.53 \\
\hline Intercropping (I) & 11 & $219.36 * *$ & 265.05 & $0.86 *$ & 7.35 & $1896.41 * *$ & $265.05 * *$ \\
\hline Y*I & 11 & 65.47 & 7.23 & $0.98 * *$ & 5.32 & 328.25 & 7.23 \\
\hline Error & 44 & 73.87 & 9.11 & 0.36 & 5.95 & 402.20 & 9.11 \\
\hline
\end{tabular}

*and** mean significant at 5 and $1 \%$ level of probability, respectively

Data presented in Table 3 reveal that cultivation hybrid 128 as sole produced the tallest maize plants $(202.00 \mathrm{~cm})$ followed by maizecowpea intercropped in the same row $(197.33 \mathrm{~cm})$ with no significant differences between two treatments. This is may be due to the competition between maize plants for intercepted the light intensity, therefore, its lead to the increase in maize plant height. Otherwise, the competition was decreased in intercropping patterns between maize and cowpea plants in cases of different growth habit. Furthermore, the highest mean value of number of rows ear $^{-1}$ (13.27) was gained from cultivated maize hybrid 131 with cowpea 1:2 rows followed by intercropped maize hybrid 128 with cowpea 2:2 rows (13.07). Moreover, the highest mean value of grain weight ear $^{-1}(143.00 \mathrm{~g})$ was produced from sole sowing of maize hybrid 128 followed by intercropped of maize hybrid 128 with cowpea 1:1 row which was gained $136.00 \mathrm{~g} \mathrm{ear}^{-1}$ (Table 4). In addition, sole planting for maize hybrid 128 surpassed sole planting for maize hybrid 131 and the other intercropping patterns with regard to grain yield feddan ${ }^{-1}$ and gained the maximum grain yield fed$\mathrm{dan}^{-1}$ which was 38.82 ardab feddan ${ }^{-1}$. This is to be logic since the same trend was observed with regard to grain weight ear ${ }^{-1}$. Here too, the intercropping maize hybrid 128 with cowpea in the same rows ranked second after sole 128 hybrid and gave 29.11 ardab feddan $^{-1}$ (Table 4). Similar trend was found by Gangwar and Sharma (1994) and Egbe et al. (2010) who reported that intercropping maize with cowpea was seen to significantly decrease ear length, dry ear weight and dry grain yield at the same of maize planting date. On the other hand, Hamd Alla et al. (2014) who stated that the highest grain yield of intercropped maize may be due to the highest values for number of ears/plant, ear length, number of rows/ear, number of grains/row and 100-grain weight, since an important yield components caused in increasing the grain yield/fed at compared the sole maize. 
Website: www.aun.edu.eg/faculty_agriculture/journals_issues_form.php E-mail:ajas@aun.edu.eg

Table 3. Effect of cowpea with maize intercropping on the plant height, Ear length and number of rows /ear of maize in 2017 and 2018 seasons and its combined.

\begin{tabular}{|c|c|c|c|c|c|c|c|c|c|}
\hline \multirow[t]{2}{*}{ Intercropping } & \multicolumn{3}{|c|}{$\begin{array}{l}\text { Plant height } \\
\text { (cm) }\end{array}$} & \multicolumn{3}{|c|}{$\begin{array}{l}\text { Ear length } \\
\text { (cm) }\end{array}$} & \multicolumn{3}{|c|}{$\begin{array}{c}\text { Number of rows } \\
\text { /Ear }\end{array}$} \\
\hline & 2017 & 2018 & mean & 2017 & 2018 & mean & 2017 & 2018 & $\mathrm{Me}$ \\
\hline Hybrid 128 & 4.67 & & & 2173 & & & & & \\
\hline $\mathrm{H} 128$ & & 33 & 7.33 & .37 & & .95 & 12.93 & 12.93 & 2 \\
\hline Row H & 2.33 & 5.00 & 193.67 & 19.51 & & 20.42 & 12.80 & 12.67 & .73 \\
\hline Row & 36.67 & 196.33 & 191.50 & 18.77 & & & 13.07 & 12.27 & \\
\hline Two & & & & 20.54 & & 20.09 & 13.07 & 12.80 & \\
\hline & & & & & & 20.21 & 33 & & \\
\hline $\mathrm{Hyt}$ & 1.00 & & & 20.67 & & 20.17 & 11.47 & 12.27 & 11 \\
\hline $\mathrm{H} 13$ & 57 & 197.00 & 33 & 20.83 & 19 & 20.38 & 12.80 & 12.67 & 12.7 \\
\hline Row 1 & 4.47 & 193.67 & 189.07 & 19.80 & 20.77 & 20.28 & 12.93 & 12.20 & 12.57 \\
\hline Row H131: two r & 177.33 & 184.67 & 181.00 & 20.73 & 20.23 & 20.48 & 13.20 & 13.33 & 13.27 \\
\hline Two rows H131: row cowp & 175.33 & 192.00 & 183.67 & 20.40 & 20.23 & 20.32 & 13.20 & 12.80 & 13.00 \\
\hline 11: two row & 193.33 & 202.00 & 197.67 & 21.27 & 20.08 & 20.67 & 13.47 & 11.00 & 12.2 \\
\hline L.S.D 0.05 for Intercropping & & 10.00 & & & - & & & 0.67 & \\
\hline
\end{tabular}

Table 4. Effect of cowpea with maize intercropping on the weight of 100 grain, grain weight/ ear and grain yield of maize in 2017 and 2018 seasons and its combined.

\begin{tabular}{|c|c|c|c|c|c|c|c|c|c|}
\hline \multirow[t]{2}{*}{ Intercropping } & \multicolumn{3}{|c|}{$\begin{array}{l}\text { Weight of } 100 \text { grains } \\
\text { (g) }\end{array}$} & \multicolumn{3}{|c|}{$\begin{array}{c}\text { Grain weight /Ear } \\
\text { (g) }\end{array}$} & \multicolumn{3}{|c|}{$\begin{array}{c}\text { Grain Yield } \\
\text { (Ardab) }\end{array}$} \\
\hline & 2017 & 2018 & M & 2017 & 2018 & Mean & 2017 & 2018 & $\mathrm{Me}$ \\
\hline $80+1$ & & & & 67 & & 00 & 37.53 & 40.10 & \\
\hline H128 & & & & 67 & & & 28.40 & & \\
\hline Row l & & 53 & & 67 & & & 25.32 & 25.51 & 42 \\
\hline Row H128: & & 34.23 & 34.87 & 127.00 & & & 17.81 & 19.98 & \\
\hline Two rows H128: 1 & & & 34.00 & & & & 16.14 & 35 & 17.74 \\
\hline & & & & & & & 24.38 & 19.72 & \\
\hline & & & & & & & 23.08 & & \\
\hline & & & & & & & 19.64 & 21.49 & \\
\hline Row 1 & & 34 & 34.07 & 118.67 & 0 & & 20.83 & 19.45 & 20.14 \\
\hline Row H131: & 6 & 34.31 & 33.23 & 128.67 & 121.33 & 125.00 & 13.43 & 12.00 & 12.71 \\
\hline Two rows H131: row co & & 35.45 & 32.39 & 123.33 & 100.67 & 112.00 & 18.48 & 19.17 & 18.82 \\
\hline Two rows H131: two rows cov & .76 & 33.56 & 32.66 & 110.67 & 60.00 & \begin{tabular}{|l|}
85.33 \\
\end{tabular} & 18.04 & 19.33 & 18.69 \\
\hline L.S.D 0.05 for Intercroppin & & ----- & & & 23.34 & & & 3.51 & \\
\hline
\end{tabular}

B- Effect of Cowpea with Maize Intercropping on Cowpea Characters

The combined analysis of variance, presented in Table 5, revealed highly significant variations among the intercropping treatments for all studied cowpea traits.

Sole cowpea crop produced highly significant forage yield (11.59 ton feddan-1 as summation of two cuts) than intercrop patterns (Table,
6). This finding is logic, since the light competition inter-and intraplants of cowpea and the maize under intercropping. It is clear that the competition between the two associated crops amplified by maize elongation and consequently its large shading on cowpea. In addition, the reduction in green forage yield was higher in the second cut than in the first cut compared with solid plant in 
both seasons. The large reduction in the second cut due to the highest competition of maize with shading effect of the taller component maize, which obstructed solar radiation from penetrating into the lower cowpea canopy, the lowest shading of young maize plants on cowpea accompanies with the lowest competitions and in consequence lowest forage yield reduction. The maximum growth and yield of cowpea was observed in single cropping. They added that the stem dry weight reduced by $52 \%$ in intercropping as compared to single cropping (Polthanee and Butchareon, 2000). In the contrary, sole cowpea crop produced significantly lower DM weight than intercrop (Table 7). The sole cowpea crop grew and matured faster because of lack of com- petition for resources such as light, water and nutrients. This caused sole cowpea plants to lose some leaves before harvesting for DM weight analysis. The loss of some leaves in the field could have lowered DM weight in the sole cowpea crop. It was observed that intercropped cowpeas matured while still holding leaves and this could be because shading by maize prevented them from drying. These finding are accordance with those obtained by Hamd Alla et al. (2014). Here too, sole cowpea crop registered the minimum fiber percent as compared with intercrop patterns. Otherwise, the highest mean value of protein percentage $(17.30 \%)$ was recorded from intercrop maize with cowpea $1: 2$ or $2: 1$ rows (Table 7).

Table 5. Combined analysis of variance for studied cowpea traits over two years.

\begin{tabular}{|c|c|c|c|c|c|}
\hline S.O.V & d.f & Forage Yield (Kg) & Dry Matter (g) & Fiber & Protein content \\
\hline Year (Y) & 1 & 47665605.92 & 3.208 & 1.907 & 1.493 \\
\hline Error Y & 4 & 4469700.60 & 0.581 & 1.900 & 0.288 \\
\hline intercropping (I) & 10 & $64317521.60^{* *}$ & $0.530^{*}$ & $7.212^{* *}$ & $0.884^{* *}$ \\
\hline Y*I & 10 & $2386999.80^{* *}$ & 0.456 & 6.433 & 0.532 \\
\hline Error & 40 & 629484.10 & 0.231 & 0.770 & 0.292 \\
\hline
\end{tabular}

*and** mean significant at 5 and $1 \%$ level of probability, respectively

Table 6. Effect of cowpea with maize intercropping on the forage yield and dry mater of cowpea in 2017 and 2018 seasons and its combined.

\begin{tabular}{|l|c|c|c|c|c|c|}
\hline \multirow{2}{*}{\multicolumn{1}{|c|}{ Intercropping }} & \multicolumn{3}{c|}{ Forage Yield (Kg) } & \multicolumn{3}{c|}{ Dry Matter (\%) } \\
\cline { 2 - 7 } & $\mathbf{2 0 1 7}$ & $\mathbf{2 0 1 8}$ & Mean & $\mathbf{2 0 1 7}$ & $\mathbf{2 0 1 8}$ & Mean \\
\hline Cowpea sole & 9.55 & 13.62 & 11.59 & 12.20 & 12.46 & 12.33 \\
\hline H128 /Cowpea in the same row & 3.23 & 4.20 & 3.71 & 13.03 & 11.85 & 12.44 \\
\hline Row H128: row cowpea & 2.56 & 4.04 & 3.30 & 13.19 & 12.25 & 12.72 \\
\hline Row H128: two rows cowpea & 4.28 & 5.21 & 4.74 & 12.79 & 12.47 & 12.63 \\
\hline Two rows H128: row cowpea & 2.36 & 3.71 & 3.04 & 13.57 & 12.32 & 12.95 \\
\hline Two rows H128: two rows cowpea & 2.84 & 3.79 & 3.32 & 12.76 & 12.58 & 12.67 \\
\hline H131 Cowpea in the same row & 3.85 & 5.02 & 4.44 & 12.90 & 12.05 & 12.47 \\
\hline Row H131: row cowpea & 3.08 & 4.15 & 3.61 & 12.24 & 12.38 & 12.31 \\
\hline Row H131: two rows cowpea & 4.63 & 6.61 & 5.62 & 12.97 & 12.99 & 12.98 \\
\hline Two rows H131: row cowpea & 2.52 & 3.70 & 3.11 & 13.35 & 13.17 & 13.26 \\
\hline Two rows H131: two rows cowpea & 3.08 & 3.40 & 3.24 & 12.89 & 12.31 & 12.60 \\
\hline L.S.D 0.05 for Intercropping & \multicolumn{7}{|c|}{0.01} & & & 0.56 & \\
\hline
\end{tabular}


Website: www.aun.edu.eg/faculty_agriculture/journals_issues_form.php E-mail:ajas@aun.edu.eg

Table 7. Effect of cowpea with maize intercropping on the fibre percentage and protein content of cowpea in 2017 and 2018 seasons and its combined.

\begin{tabular}{|c|c|c|c|c|c|c|}
\hline \multirow{2}{*}{ Intercropping } & \multicolumn{3}{|c|}{ Fibre percentage (\%) } & \multicolumn{3}{c|}{ Protein content (\%) } \\
\cline { 2 - 7 } & $\mathbf{2 0 1 7}$ & $\mathbf{2 0 1 8}$ & Mean & $\mathbf{2 0 1 7}$ & $\mathbf{2 0 1 8}$ & Mean \\
\hline Cowpea sole & 24.47 & 23.40 & 23.93 & 17.03 & 16.90 & 16.96 \\
\hline H128 /Cowpea in the same row & 25.10 & 25.23 & 25.16 & 17.43 & 17.00 & 17.21 \\
\hline Row H128: row cowpea & 23.25 & 22.37 & 22.81 & 16.70 & 16.70 & 16.70 \\
\hline Row H128: two rows cowpea & 23.81 & 23.95 & 23.88 & 16.63 & 16.73 & 16.68 \\
\hline Two rows H128: row cowpea & 23.59 & 24.07 & 23.83 & 16.68 & 16.30 & 16.49 \\
\hline Two rows H128: two rows cowpea & 21.83 & 24.00 & 22.91 & 16.02 & 16.02 & 16.02 \\
\hline H131 Cowpea in the same row & 25.81 & 21.34 & 23.58 & 16.88 & 16.88 & 16.88 \\
\hline Row H131: row cowpea & 23.98 & 20.83 & 22.41 & 16.71 & 17.25 & 16.98 \\
\hline Row H131: two rows cowpea & 22.97 & 24.08 & 23.52 & 18.20 & 16.40 & 17.30 \\
\hline Two rows H131: row cowpea & 19.59 & 22.01 & 20.80 & 17.65 & 16.95 & 17.30 \\
\hline Two rows H131: two rows cowpea & 23.09 & 21.91 & 22.50 & 17.30 & 16.85 & 17.08 \\
\hline L.S.D 0.05 for Intercropping & \multicolumn{7}{|c|}{1.024} & & 0.631 & \\
\hline
\end{tabular}

\section{C- Land Equivalent Ratio(LER)}

The mean LER values were always greater than 1.0 especially when cultivate maize hybrid 131 with cowpea (Table 8). So intercropping showed an advantage over sole cropping. The highest mean value of LER
(1.25) was achieved from intercrop pattern of maize and cowpea in the same row side to side followed by 1.22 LER which was achieved from intercrop pattern of maize and cowpea 1:1 row. Similar findings are approved by Hamd Alla et al. (2014).

Table 8. Effect of cowpea with maize intercropping on the Land Equivalent Ratio (LER).

\begin{tabular}{|l|c|}
\hline \multicolumn{1}{|c|}{ Intercropping } & Land Equivalent Ratio (LER) \\
\hline H128 /Cowpea in the same row & 1.094 \\
\hline Row H128: row cowpea & 0.942 \\
\hline Row H128: two rows cowpea & 0.922 \\
\hline Two rows H128: row cowpea & 0.676 \\
\hline Two rows H128: two rows cowpea & 0.946 \\
\hline H131 /Cowpea in the same row & 1.253 \\
\hline Row H131: row cowpea & 1.224 \\
\hline Row H131: two rows cowpea & 1.066 \\
\hline Two rows H131: row cowpea & 1.064 \\
\hline Two rows H131: two rows cowpea & 1.104 \\
\hline
\end{tabular}

\section{Conclusion}

In conclusion, the productivity of a unit land area is improved by intercropping rather than sole crop. Results indicated that intercropping had a major advantage over sole cropping on the LER particularly when the maize and cowpea were planted within the same basin. We recommend that planting of cowpea with maize mixture should be $100 \%$ cowpea: $100 \%$ maize (cowpea intercrop on the other side of maize rows).

\section{References}

A.O.A.C. (1995). Association of Official Analytical Chemists. Official methods of analysis, $16^{\text {th }}$ Ed., AOAC International, Washington, D.C., USA. 
Egbe, O. M., S. E. Alibo, and I. Nwueze (2010). Evaluation of some extraearlyand early- maturing cowpea varieties for intercropping with maize in southern guinea savannah of Nigeria. Agriculture and Biology Journal of North America.

Hamd Alla, W.A.; E. M. Shalaby., and R.A. Dawood., A.A. Zohry (2014). Effect of Cowpea (Vigna sinensis L.) with Maize (Zea mays L.) Intercropping on Yield and Its Components Journal of Agricultural and Biosystems Engineering Vol:8, No:11

Gangwar, K. S., and S. K. Sharma (1994). Fodder legume intercropping in maize (Zea mays) and its effect on succeeding wheat (Triticum aestivum). Indian Journal of Agricultural Sciences, vol., 64. pp. 38-40. 1994.

Gomez, K.A. and A.A. Gomez (1984). Statistical Procedures for Agricultural Research. $2^{\text {nd }}$ Edn., John Wily and Sons, New York, pp: 68.

Okpara, D. A. (2000). Growth and yield of maize and vegetable cowpea as influenced by intercropping and nitrogen fertilizer in the low land humid tropics. J. Sustainable Agric. and the Environ. Vol., 2. pp.188-194.
Polthanee, A. and S. Butchareon (2000). Comparison of single cropping, intercropping and relay cropping of corn with cowpea under rained conditions in an upland area of northeastern Thailand. J. ISSAAS vol., 6. pp.1-12.

SAS institute (2008). The SAS System for Windows, release 9.2. Cary NC: SAS institute.

Shata, S. M., S. A. Mahmoud and H. S. Siam (2007). Improving calcareous soil productivity by integrated effect of intercropping and fertilizer dorycnium rectum. Res. J. of Agri. and Biolo. Sciences, vol., 3. pp.733-739.

Snedecor, G. W. and W.G. Cochran (1989). Statistical Methods, Eighth Edition, Iowa State University Press.

Willey, R. W. and S.O. Osiru (1972). Studies on mixture of maize and beans (Phaseolus vulgaris) with particular reference to plant populations. J. Agric. Sci. Camb. Vol., 79. pp. 519-529.

Zohry, A. A. (2005). Effect of preceding winter crops and Intercropping on yield, yield components and associated Weeds in maize. Annals of Agric. Sc., Moshtohor, vol., 43. pp. 139-148. 
Website: www.aun.edu.eg/faculty_agriculture/journals_issues_form.php E-mail:ajas@aun.edu.eg

\section{تأثير تحميل الذرة الثامية مع اللوبيا علي المحصول وجودته}

سماح محمد السعيد، محمد عبد المنعم المرشدي ، إنعام حلمي جلال ، فتحي محمد فتحي عبد المتجلي ومحمود عبد اللطيف محمد عبد الله جله

$$
\begin{aligned}
& \text { ' قسم المحاصيل - كلية الزر اعة - جامعة اسيوط } \\
& \text { ' قسم الإنتاج الحيو اني - كلية الزر اعة اعة جامعة اسيوط السيوط }
\end{aligned}
$$

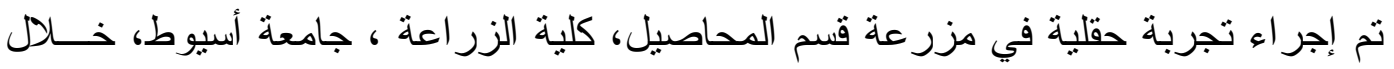

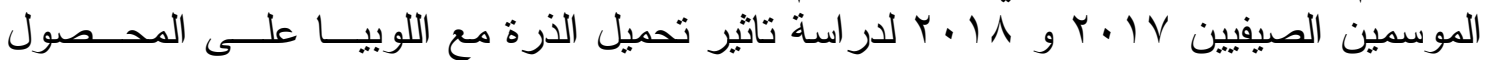

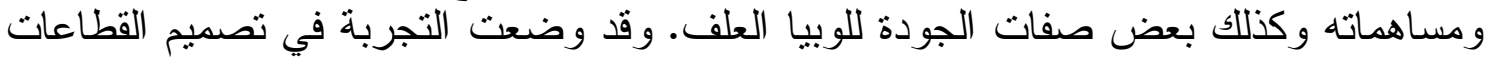

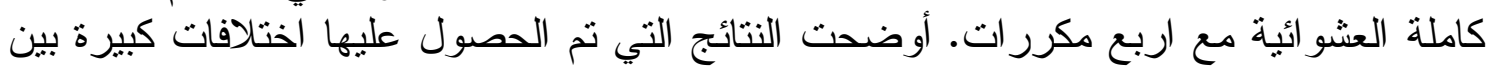

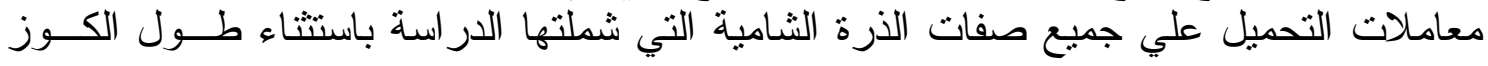

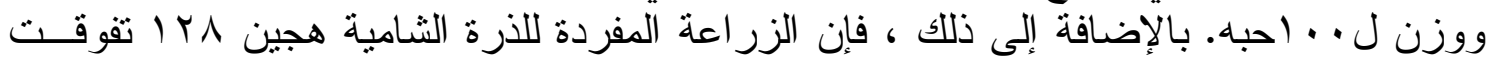

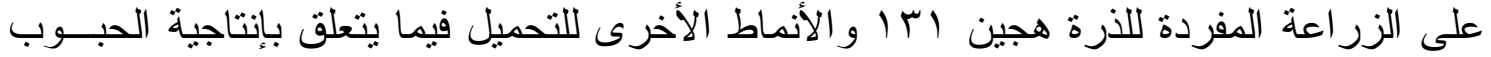

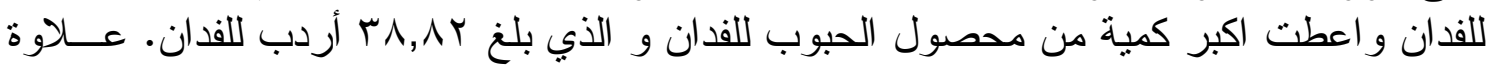

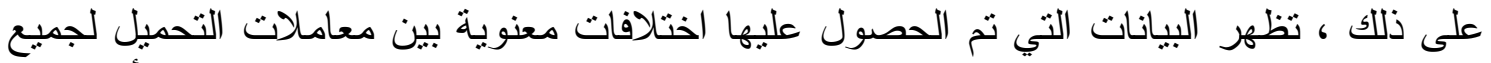

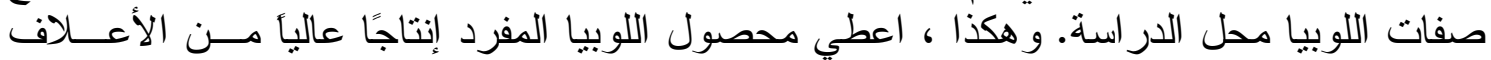

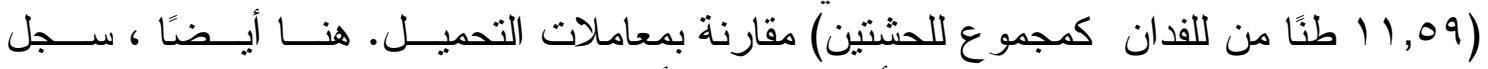

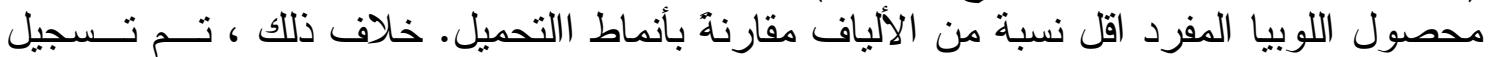

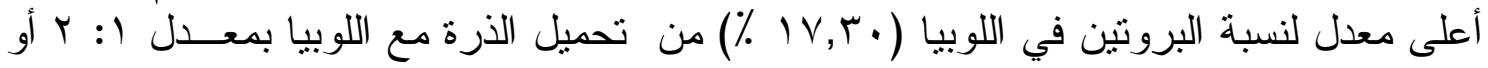

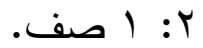

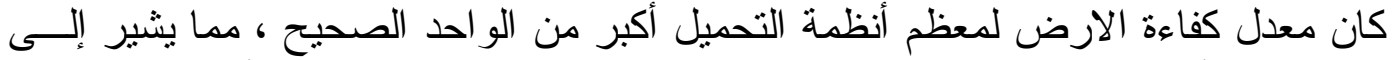

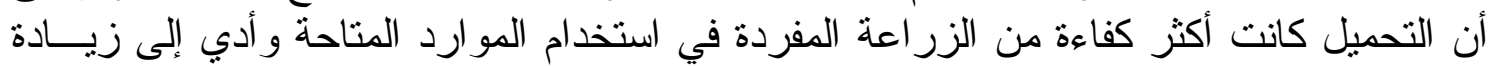

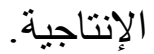

